\title{
Políticas de la virilidad. Masculinidades en el cine policial y criminal de Carlos Hugo Christensen en Brasil (1960-1970)
}

\section{Cecilia Nuria Gil Mariño}

Alexander von Humboldt Stiftung-PBI, Universität zu Köln - Consejo Nacional de Investigaciones Científicas y Técnicas -Universidad de San Andrés, Argentina cecigilmarino@gmail.com

\begin{abstract}
Resumen
Durante varias décadas, la crítica nacional brasileña colaboró con la estigmatización de los géneros cinematográficos identificándolos con el imperialismo cultural y diferenciando a sus realizadores entre autores y artesanos. Esto impactó en el desarrollo de una historiografía que privilegió al cine de autor. No obstante, el cine policial, criminal, el terror y sus monstruos constituyen un espacio discursivo privilegiado a la hora de pensar los miedos, las ansiedades y las formas de violencia de una sociedad en relación con las matrices culturales binarias de las imágenes y discursos de lo masculino y lo femenino.
\end{abstract}

En este sentido, el presente trabajo aborda la filmografía de Carlos Hugo Christensen en Brasil, referente ineludible de los orígenes del género policial en la Argentina, para indagar la potencialidad política de estos objetos de la cultura de masas desde una perspectiva de género. Se buscará analizar las relaciones entre las desestabilizaciones del orden y la ley como institución masculina que se plantean en el género policial y criminal, con las de la heteronormatividad a través de la puesta en escena de subjetividades que desafían o ponen en cuestión las relaciones de poder de las masculinidades.

Palabras clave: masculinidades; cine policial; cine brasileño; monstruo; política de la virilidad.

Politics of virility. Masculinities in the police and criminal cinema of Carlos Hugo Christensen in Brazil (1960-1970)

\begin{abstract}
For several decades, Brazilian national critics have contributed to the stigmatization of film genres by identifying them with cultural imperialism and differentiating their filmmakers between authors and artisans. This had an impact on the development of
\end{abstract}


a historiography that privileged auteur cinema. However, police and criminal films, terror and its monsters constitute a privileged discursive space when it comes to thinking about the fears, anxieties and forms of violence of a society in relation to the binary cultural matrices of images and discourses of the masculine and the feminine.

In this sense, the present work deals with Carlos Hugo Christensen's filmography in Brazil, an unavoidable reference of the origins of the detective and criminal genres in Argentina, to investigate the political potential of these objects of mass culture from a gender perspective. I will seek to analyze the relationships between the destabilization of order and law as a male institution that are posed in the police, detective and crime genres, with those of heteronormativity through the staging of subjectivities that challenge or question the power relations of masculinities.

Keywords: masculinities; crime film; Brazilian cinema; monster; manhood policy.

\section{Sobre géneros cinematográficos y masculinidades en el cine brasileño}

Las dificultades por afianzar un proyecto industrial de cine en Brasil, así como la consolidación de movimientos de vanguardia como el Cinema Novo en la década de 1960, colaboraron con la estigmatización de los géneros cinematográficos por parte de la crítica nacional que los identificaba con el imperialismo cultural y diferenciaba a sus realizadores entre autores y artesanos. José Mário Ortiz Ramos (1993:111) señala que "la extrema atención dedicada al filme de autor -con trabajos sin duda significativos-, sumada a un intenso énfasis ideológico, condujeron a un desprecio por la narrativa del entretenimiento". El autor agrega, asimismo, que la dificultad para pensar los géneros está ligada a un punto de estrangulamiento de la reflexión brasileña como lo es la cuestión de la cultura popular en una sociedad modernizada. Así, la historiografía del cine delineó una serie de ausencias que en las últimas décadas comenzaron a ser problematizadas desde diversos enfoques.

Una buena parte de estas investigaciones, que proponen nuevas perspectivas sobre los géneros, retoman los trabajos de Rick Altman (2000) y Jason Mittel (2004) que plantean pensar las "formas mutantes" bajo las cuales la categoría genérica opera culturalmente y los modos en que estos textos son apropiados por sus usuarios de maneras distintas; el género es comprendido, así, como un conjunto de expectativas compartidas. En esta misma dirección, en los últimos años, el trabajo de Rafael de Luna Freire (2011a, 2011b) ha propuesto repensar la discusión en torno a lo nacional y los géneros cinematográficos en Brasil. Con respecto al policial en particular, a partir de una vasta investigación histórica sobre la producción y exhibición del género en el país, Freire plantea correrse de los esencialismos y resaltar el carácter coyuntural de cómo determinados filmes se entendieron como brasileños y policiales en diferentes momentos (2011: 84). Otro estudio destacable en este sentido es el de Laura Loguercio Cánepa (2008), quien, en su análisis sobre el terror en el cine brasileño, remarca que su ausencia es más historiográfica que histórica y analiza cómo el terror se expresó en hibridez con otros géneros más populares en la época. Como en varios países de la región, esta hibridez tuvo como resultado la configuración de versiones domésticas de suma peculiaridad del policial, del noir, del melodrama fantástico, del gótico, entre otros.

El presente trabajo tiene como objetivo abordar la potencialidad política de estos objetos de la cultura de masas partiendo de que estos géneros cinematográficos vernáculos 
tuvieron el potencial de forjar un espacio que habilitaba las transgresiones sociales y sexuales, al mismo tiempo que las contenían. El cine policial, criminal, el terror y sus monstruos constituyen un espacio discursivo privilegiado a la hora de pensar los miedos, las ansiedades y las formas de violencia de una sociedad en relación con las matrices culturales binarias de las imágenes y discursos de lo masculino y lo femenino. Estos filmes, así, se vuelven vías de entrada fértiles para pensar cómo se configuraron experiencias comunes de la violencia desde las imágenes cinematográficas y mediáticas en general. El asesino, el ladrón, el pederasta, el pedófilo, el monstruo forjan figuras de la alteridad frente al ciudadano civilizado, al mismo tiempo que su naturaleza anómala pone en cuestión las características del orden patriarcal civilizatorio de los proyectos político-culturales latinoamericanos, expresan pulsiones reprimidas y repreguntan sobre la tolerancia a la diferencia.

De esta manera, estas películas pusieron en circulación diferentes representaciones de las masculinidades que dialogaron tanto con las reglas de los géneros como con las tensiones históricas de su tiempo. A su vez, en el cine de Christensen, estas figuras masculinas que infringen el orden social también transgreden la moral sexual. En relación con su la trilogía noir a inicios de los años cincuenta en Argentina, Emilio Bernini (2021: 187) propone que "entre el policial noir y la homosexualidad pregay -es decir no normada ni normativa- hay una relación estrecha y sutil que involucra problemas que son a la vez estéticos, identitarios, políticos, literarios y cinematográficos". Asimismo, el crítico lanza una serie de preguntas sumamente interesantes.

¿Qué relación hay entre hábitos sexuales no visibles, no normados, y el noir como expresión de esa invisibilidad o de una apariencia que siempre es equívoca, que encubre y a la vez devela, con la incertidumbre de los móviles de los actos? ¿Qué vínculo hay entre la persecución de la víctima inocente, el error de juicio, el amor desplazado y la cultura homosocial, represiva y culpabilizante? (Íd.).

Considerando los aportes de los interrogantes de Bernini para el período clásico en Argentina, este estudio indaga la obra de Christensen en Brasil -país en el que se estableció a partir de 1954 y donde desarrolló una filmografía tan vasta como heterogénea- respecto de los vínculos entre el cine policial y criminal y las imágenes de las masculinidades. En este nuevo escenario, Christensen radicalizó su crítica a los modelos masculinos hegemónicos y de poder, al incorporar el homoerotismo y el deseo por el mismo sexo en tensión con la represión y censura social y de la ley. Así, sus películas presentaron desafíos a la heteronormatividad al poner en escena subjetividades menos definidas por las reglas de una binaridad fija de la identidad sexo-genérica.

Es por ello que este estudio busca hacer una relectura de estas películas a partir de aquellos trabajos que desde la década de 1990 han complejizado la idea de roles sexuales y de género, a partir de los estudios de Judith Butler (2007) sobre la teoría de la performatividad del género y el desarrollo del movimiento queer. La masculinidad como modelo homogéneo comenzó a ser cuestionada, considerándose variables como la clase social, la etnia, la edad, la política y la geografía. Jack Halberstam (2008) abordó la marginación de masculinidades alternativas y la diferencia con la política de la virilidad, así como también señaló la capacidad de plantear una existencia para estas imágenes que, aunque negativas, existieron en la historia del cine y crearon representaciones posibles.

Por su parte, el trabajo de Connell (1997: 35) remarca que el concepto de masculinidad "es al mismo tiempo la posición en las relaciones de género, las prácticas por las cuales los hombres y mujeres se comprometen con esa posición de género, y los efectos de estas prácticas en la experiencia corporal, en la personalidad y en la cultura", enfatizando que se trata de un proceso histórico que involucra al cuerpo y 
no a un conjunto de determinantes biológicas. Así, la masculinidad hegemónica no es un tipo de carácter fijo, sino la que ocupa la posición hegemónica en un modelo dado de relaciones de género.

se puede definir como la configuración de practica genérica que encarna la respuesta corrientemente aceptada al problema de la legitimidad del patriarcado, la que garantiza (o se toma para garantizar) la posición dominante de los hombres y la subordinación de las mujeres. (Ibíd.: 39)

Entonces, las masculinidades hegemónicas y las marginadas no son tipos fijos, sino configuraciones de prácticas generadas en situaciones particulares, en una estructura cambiante de relaciones (Ibíd.: 43).

Con respecto al cine brasileño, uno de los trabajos que colaboró con la apertura de nuevos caminos para repensar las masculinidades ha sido la tesis de Antonio Moreno (2001), que indaga la representación de la homosexualidad desde la década de 1920 y concluye que la tendencia mayoritaria es que los homosexuales sean presentados como individuos enfermos, asociados al crimen, la prostitución y el vicio, cuyos destinos son trágicos la mayoría de las veces. Según el autor, también se los representa de manera grotesca, como objeto de burla, con una gestualidad excesiva y vestuarios extravagantes.

No obstante, tal como señala James Hodgson en su tesis doctoral, el enfoque de Moreno parte de una concepción fija de la identidad sexo-genérica.

\begin{abstract}
Moreno aboga por las representaciones del 'buen ciudadano homosexual' -un antídoto para el varón afeminado, y uno capaz de satisfacer el deseo de participación en la sociedad- que realiza la asimilación dentro de la política de identidad gay y lesbiana. Su llamamiento a las representaciones de homosexuales masculinos y normalizados invoca una concepción fija de la identidad sexo-genérica, que apoya la noción burguesa de un sujeto estable (Hodgson, 2012: 34).
\end{abstract}

Asimismo, Hodgson, siguiendo a Denilson Lopes (2004) y João Bösco Hora Góis (2002), plantea que la aparición de los estereotipos puede pensarse como punta de lanza para la posibilidad de su disolución a partir de la dinámica de los conflictos sociales de cada contexto. Hodgson, a partir de un marco interpretativo influido por la teoría queer, se propone investigar de qué manera, en diferentes géneros y movimientos del cine brasileño de los años 1960 y 1970, la representación del deseo del mismo sexo podría llevar a cuestionar la noción de identidad sexo-genérica como algo fijo o estable, y cómo estas películas tienen la capacidad tácita o accidental de perturbar las estructuras sociales opresivas.

Así, a partir de estos aportes, se buscará analizar en O menino e o vento (1966), Anjos e demônios (1969) y A morte transparente (1978) las relaciones entre las desestabilizaciones del orden y la ley como institución masculina que se plantean en el género policial y criminal, con las de la heteronormatividad a través de la puesta en escena de subjetividades que desafían o ponen en cuestión las relaciones de poder de las masculinidades.

\title{
2. El monstruo y la ley
}

Rafael de Luna Freire (2011: 165) señala que desde las primeras décadas del siglo XX los filmes de mysterio - según la grafía de la época- en Brasil se constituían como objetos transmediáticos que abrevaban en elementos de la matriz cultural sensacionalista, como la fascinación por el otro monstruoso, no solamente fantástico o 
exótico, sino también aquel asesino que puede estar escondido entre la gente en el anonimato de la gran urbe, con una visión fuertemente moralizadora de sanear la ciudad. Freire analiza la popularidad del género y sostiene que, si bien a inicios de la década de 1940 se percibe un cansancio entre los críticos de cine, crece el éxito en el radioteatro gracias a los seriales donde la ley siempre triunfa acorde al nacionalismo estadonovista de la época.

Este vínculo entre el Estado y el policial también tuvo lugar durante el primer peronismo en la Argentina, aunque en el caso de Christensen, tal como plantea Bernini (2021: 188), la trilogía noir responde a la narración de la oscuridad del mundo de la perversión sexual del noir, a la vez que impone no tanto la ley como la luz moral de la conciencia. Así, se enuncia a la vez la transgresión y la ley, deseo y condena. Es por esta razón que se ha decidido en este trabajo incluir un filme como O menino e o vento (1966), ya que en la primera parte se vale de los elementos del noir, mientras que en la segunda se convierte en un drama judicial donde el juicio criminal se confunde con el moral (Primati, 2015a).

La película es considerada pionera en un tratamiento más sensible sobre la homosexualidad. Moreno (2001) señala que a partir de 1960 creció el número de filmes que abordaban la temática, aunque la preponderancia de temas socio-políticos más amplios no fue una característica extendida. El filme transcurre en una pequeña ciudad del interior de Minas Gerais sin mucho atractivo pero conocida por los vientos que soplan en la región. José, un ingeniero joven con un buen pasar económico, viene desde Río de Janeiro llamado por la justicia porque es acusado de la desaparición -y tal vez asesinato- de un joven pobre llamado Zeca da Curva. La estética noir predomina en toda la primera parte, donde se profundiza la grieta entre él -el monstruo, el asesino, el homosexual, el extranjero, pero también el objeto de deseo- y el pueblo que busca venganza. Desde lo formal, en el montaje se alternan planos de la muchedumbre, close de los rostros enfurecidos y primeros planos del rostro de José. El juego con los claroscuros de la luz refuerza la idea de la hipocresía y la censura. Todos los encuentros que tiene José están atravesados por el chantaje económico o sentimental; el abogado que busca que confiese su vínculo sexual con el muchacho, la dueña de la pensión que está enamorada de él e insinúa que puede morigerar su testimonio a cambio de su cariño, o bien el primo con dinero de Zeca, quien le confiesa su homosexualidad y le ofrece su ayuda a cambio de su amistad. La segunda parte se estructura a partir del juicio y los testimonios de los diferentes testigos, a modo de flashback, van retratando la historia. El último en hablar es José, quien asevera su inocencia y relata su amistad con Zeca por compartir la misma pasión por el viento. El muchacho le demuestra que tiene la capacidad de evocar al viento y su última noche en el pueblo le muestra el más intenso de todos, el ventão. Tras él, desaparece y no lo vuelven a ver.

Todo el relato del vínculo, desde lo narrativo y lo formal, está atravesado por la analogía entre el deseo homosexual y la pasión por el viento. El viento es metáfora de la libertad y de "una fuerza incontrolable", como lo es el deseo. Hodgson también señala cómo el viento constituye una imagen háptica. La película está plagada de este tipo de imágenes que expresan la tensión entre el deseo irrefrenable de tocar y la represión social; la dueña de la pensión que toca la ropa de José, los planos del cuerpo de Zeca con el torso desnudo recibiendo el viento, con ojos cerrados entregado al erotismo del viento, el agua en su cuerpo, su camisa en manos de José. Cuando el ingeniero le pregunta cómo sabe que el viento viene, el muchacho responde que con el cuerpo. En cuanto sus cuerpos se encuentran, finalmente, por un momento, Zeca desaparece en el viento. La cámara parece seguir la irracionalidad del soplido del viento enfatizando la tensión entre la lógica y el instinto. En su testimonio, José cuenta que eligió ser ingeniero para ser un hombre práctico, con sentimientos explicables, libre del abismo, 
hasta que vio a Zeca en el viento. A partir de ese momento, se generó una "curiosa camaradería", unidos en una misma pasión por el viento. Confiesa que resistió, pero que ahora ya no puede vivir sin el viento.

Más adelante, al confundir al viento con el propio Zeca -"mi mente comenzó a confundir muchacho y viento. No sabía si el viento venía porque Zeca estaba o si Zeca aparecía porque ventaba"-, transforma la fascinación en deseo: estar enamorado del viento es estar enamorado de Zeca (Hodgson, 2012: 138). El final de carácter fantástico, con el viento que entra en el tribunal y arrasa con todo menos con el ingeniero, que se queda acariciando la camisa de Zeca, es leído por Moreno (2001) como la revelación de su homosexualidad, como una fuerza de la naturaleza que no se puede matar como dice José refiriéndose al muchacho-, mientras que Hodgson propone que esa total destrucción demuestra la capacidad de abolir o suspender una subjetividad fija. "José está solo, rodeado por el viento, acariciando la camisa de Zeca. Ha derribado el aparato que pretendía oprimirle mediante una identidad homosexual impuesta (el juicio). Su destino después de esto sigue siendo incierto" (Hodgson, 2012: 141).

José no niega, ni afirma. No interrumpe. Se trata de un hombre comprometido con una muchacha, viaja con una foto de ella, pero esto no lo exime de ser objeto de deseo de hombres y mujeres, así como tampoco de ser sujeto deseante. Sobre el actor, Enio Gonçalves, Christensen afirma: "En estos 14 años en Brasil, nunca vi en el cine brasileño una imagen de actor masculino joven más fascinante que la de Enio Gonçalves. Diría que, con él, nace el primer actor-galán del cine nacional" (Alencar, 1966: 5). De este modo, Christensen construye un personaje que es tanto objeto como sujeto erótico, fluyendo entre lo pasivo y lo activo, algo que la política de la virilidad del patriarcado busca fijar. Entonces, retomando la propuesta de Hodgson, su identidad y sus preferencias sexo-genéricas se presentan como fluidas, no fijas, y por ende puede ser visto como figura de lo queer, disruptora del orden. Es por ello que no puede nombrarse, no hay términos posibles en esa sociedad opresora: "siento una cosa", dice Zeca para explicar cómo sabe cuándo viene el viento. El viento como imagen de lo que fluye y no es estático.

La oposición entre los "normales" y los "monstruos" se construye tanto desde lo formal como desde el guion narrativo, como se señalaba anteriormente. José en el juicio dice que "si todos aquí se creen normales, entonces yo soy anormal, no lo digo como ofensa, sino como una observación. Porque yo no me siento como todos". Detrás del estrado del juez, está la presencia de la cruz católica, enfatizando el lugar de la moral.

Tal como plantea Gabriel Giorgi, el hombre como modelo normativo se recorta contra la singularidad radical de lo monstruoso. El autor apunta también que la cultura latinoamericana fue trazando límites con el monstruo al mismo tiempo que indicó su convivencia con los hombres, incluso su vecindad o intimidad. Así, se entiende a "la monstruosidad no como exterior y pura alteridad respecto del hombre, sino como un 'interior externalizado' de lo humano" (Giorgi, 2009: 325). En su trabajo, Giorgi aborda esta tipología de lo monstruoso para pensar las relaciones de dominación y su inversión, su narración oblicua y su producción de lenguaje político. En este sentido, el filme de Christensen puede leerse como una revalorización del monstruo, de lo anormal, que diluye las relaciones de dominación de la masculinidad hegemónica por su propia inestabilidad, que no tiene lenguaje, porque requiere de otro nuevo, que barra con todo para poder ser. El monstruo es el que pone en jaque al orden y por eso es condenado y se lo diferencia de la identidad homosexual fija, funcional al sistema patriarcal, representada en la figura de Mário, el primo rico de Zeca, como propone Hodgson. Mário busca igualarse a José hablando en primera persona del plural, utilizando un nosotros inclusivo como minoría. Se define como anormal y remarca la importancia de protegerse entre ellos, como los judíos o los comunistas. 
Aquí el guion dialoga con el contexto represivo de la época, aunque tal vez responda más a una mirada sobre el peronismo, ya que Christensen se caracterizaba por no manifestarse sobre política, salvo respecto a Perón, del cual era un ferviente opositor.

El personaje de Mário representa la figura del entendido. En los años sesenta, el término se refería a una persona que conocía las subculturas homosexuales en los espacios urbanos de Brasil, una especie de paraguas para quienes experimentaban deseo por personas del mismo sexo, pero no se categorizaban en la feminización; de este modo, cambiaban el estigma por la invisibilidad o el closet (Hodgson, 2012: 23). Según Hodgson, el filme resalta la complicidad entre el entendido y el orden social -homofóbico-y responde a la ideología heterosexista, que coloca en posición subordinada a la homosexualidad (Ibíd.: 95). La película contrasta así dos formas de homosexualidad, una cómplice del orden social y la otra fugitiva de la lógica binaria sobre la cual ese orden se funda (Ibíd.: 143).

Por último, cabe señalar otro aspecto que puede rastrearse a lo largo de la obra de Christensen: la diferencia generacional en el deseo sexual y la incomodidad, repudio o condena por esa diferencia. Esto aparece de modo más extremo en filmes como Si muero antes de despertar (1952), donde hay un violador y asesino de niñas, pero también en películas como El ángel desnudo (1946), donde la joven Olga Zubarry, para salvar a su padre, debe mostrarse desnuda ante el personaje de Guillermo Battaglia, quien estaba enamorado de su madre. O menino e o vento es una trasposición del cuento de Aníbal Machado "O iniciado do vento" (en Histórias reunidas, 1959). En el cuento Zeca es más pequeño, como remarca Hodgson. Este autor señala que el cambio de edad resalta la posibilidad de una relación sexual entre los personajes; sin embargo, en la película todos se refieren a Zeca como "o menino", "o garoto", subrayando las diferencias de edad y de clase entre el ingeniero y él. Siguiendo el planteo sobre la heterogeneidad de las masculinidades a partir de variables como la clase y la edad -y las consecuentes relaciones de poder-, podemos percibir cómo la relación entre José y Zeca tensiona estas diferencias. Por un lado, Zeca es presentado como un menor, pero al mismo tiempo existe una sexualización latente de su cuerpo; por otro, José declara en el juicio que inicialmente creyó que la simpatía de Zeca perseguía alguna propina, pero que luego se dio cuenta de que en verdad era un apasionado del viento como él. Cabe agregar que el afiche para promocionar el filme en los diarios contenía la leyenda "¿Qué extraña fascinación ejercía aquel chico sobre un hombre adulto?" (s.a., 1967: 6). Esto invertía la relación de poder una vez más: en lugar de objeto de deseo, Zeca es el hechicero que despierta esa pasión irracional.

Con respecto a su contexto de apropiación, esta ambigüedad que escapa de la identidad fija fue leída con incomodidad por parte de la crítica de la época. Muchas de las reseñas del filme resaltaban el carácter de lo anormal y lo extraño, y la idea de una verdad que se revela, pero no se sabe cómo nombrar. "En ese escenario desolado, un episodio misterioso, con síntomas de violencia criminal y anormalidad sexual" (s.a., 1966a: 1). En esa misma reseña, se resalta que José narra la "verdadera" historia y el viento impone "su fuerza irresistible y solemne, barriendo gente y cosas, como si predicara una lección y diera a la ciudad una nueva fisonomía (...) y el pueblito, después del castigo ganó otro ánimo, tal vez hasta otras características morales" (Íd.). Otra crítica del mismo diario, unos días después, remarcaba también que la amistad entre ambos "es un capítulo extraño" que provoca toda serie de rumores y que, al final, se descubren los sentimientos que "estaban asfixiados" (s.a., 1966b: 10). No obstante, la de Salvyano Cavalcanti de Paiva puso sobre la mesa la cuestión de la homosexualidad criticando principalmente la vaguedad e indefinición de Christensen sobre el tema: "un talento contenido por un indisimulable miedo de desagradar. Ahí residiría el defecto fundamental de O menino e o vento. (...) ¿Una historia escabrosa de homosexualidad? ¿Será esto lo que la cinta de Christensen quiere ser y no es? Sería 
arriesgado una afirmación taxativa" (Cavalcanti de Paiva, 1967:2). El crítico continúa señalando que el filme, en lugar de detenerse en la atracción por la naturaleza -el viento-, se demora en la fascinación de una criatura humana sobre otra, y lo que esto acarrea socialmente.

¿La sospecha de relaciones ilícitas entre el adulto y el muchacho constituyen material suficientemente fascinante para una realización cinematográfica? [...] Para interpretar la fuerza "irresistible" del viento, acaso a Christensen le faltó esta vez el vigor necesario. Aun cuando se trata de un director académico, en su estilo, en su escuela, el filme tiene valores revelados por la mitad u ocultos por temor, timidez o error de cálculo. Esto es lamentable: en lugar de una película nebulosa, como resultó, podría haber salido una de alta categoría (Íd.).

Es posible pensar que la "extrañeza", lo "a medias", que desestabiliza el orden binario, haya sido una manera de evitar problemas con la censura de la época. Cavalcanti de Paiva lo reclama como temor o error, reprocha la falta de definición, de estructura, de las reglas de un cine que dialoga con determinadas matrices político-culturales. Así, podría decirse que la película realiza una tercera operación de desestabilización -las otras dos dadas por el fracaso de la ley en la resolución del caso y el desafío a la heteronormatividad- en el plano de la crítica cinematográfica.

\section{Los jóvenes demonios y la ley}

Christensen afirmó en diversas entrevistas que uno no podía elegir la ciudad donde nacer, pero sí en la cual morir, y para él, esa ciudad era Río de Janeiro, y así lo fue. Su llegada a Río estuvo marcada por una fascinación que se tradujo en la producción de una serie de comedias coloridas que resaltaban el carácter de cidade maravilhosa de la entonces capital carioca. No obstante, hacia fines de la década de 1960, se observa el fin de la luna de miel entre el director y la ciudad, a través de una serie de filmes donde la iconografía urbana cambia de signo. La zona sur de Río de Janeiro, con sus playas hermosas y sus modernos edificios, con la música local que acompaña el placer, deja lugar al retrato de la violencia urbana, la delincuencia juvenil y la inmoralidad social. Afrânio Vital, quien trabajó como segundo asistente de dirección de Christensen y debutó profesionalmente en el filme Anjos e demônios (1969), en una larga entrevista hecha por mí, relató la desilusión de Christensen con los cambios de sociedad de la época y su universo de Copacabana. El filme que marca esta ruptura es justamente Anjos e demônios. Carlos Primati (2015) señala que "el cine de Christensen finalmente asimilaba la cara horrenda de un mundo en el que Charles Manson era una especie de bestia apocalíptica anunciando el fin del Verano del Amor".

No obstante, sus planteos no son en términos de clase, sino que postula una mirada en clave generacional del conflicto social, en este caso, en el seno de la clase acomodada carioca. Christensen coloca a la juventud como centro de la decadencia. En la escena del juicio, se introduce un discurso muy conservador de pedido de mano dura por parte de uno de los jueces que exclama que debe ser modificada la ley que ampara a los menores de edad de ser imputados porque es la juventud "la que comete crímenes frente a un cinismo inigualable entre los adultos, y debe ser juzgada en los términos del crimen y no de la edad". En la escena siguiente, el abogado se suicida: de esa manera el montaje resalta la culpabilidad de los jóvenes protagonistas. Parte de la prensa también destacó este aspecto. OJornal do Brasil en una pequeña reseña sobre la película remarca que ésta defiende la tesis de muchos juristas que consideran "anticuada" la legislación que ampara a los menores de 18 años: "por la propia evolución de los tiempos, esa juventud que comete crímenes debe ser juzgada en los términos del crimen" (s.a., 1970: 4). 
El filme sigue las reglas del género policial. Virginia es una muchacha huérfana que vive con su tío Marcos, un viejo rico, en un lujoso departamento de Copacabana. Bonita y rebelde, Virginia frecuenta y organiza fiestas con mucho alcohol, tabaco, drogas, sexo y rock and roll. En una de esas fiestas en su departamento, se enamora de un ladrón, Paulo -interpretado por el mismo actor que $O$ menino e o vento, Luiz Fernando Ianelli-, que entra sin que lo vean para robar. Ella lo encuentra y desde ese momento comienzan un romance. Juntos abusan de otra pareja de jóvenes y para evitar el escándalo, el tío llama al abogado para que libere a su sobrina del problema. Virginia acaba seduciendo al abogado para que mate a su tío y, así, poder quedarse, junto con Paulo, con toda la fortuna. El abogado, convencido de que Virginia lo ama, mata al tío Marcos; a partir de entonces, comienza a ser chantajeado por Paulo, quien afirma que lo ha visto. En el juicio en su contra, tal como ya se ha mencionado, el abogado se suicida con una pastilla. No obstante, el final es sorpresivo, ya que el tío sobrevivió y la policía llega para apresar a Virginia y Paulo.

El policial le permite a Christensen ser menos conciliador sobre un espacio geográficosocial que no puede esconder la violencia cotidiana con la vista bonita de la orilla del mar. La playa aquí ya no es el escenario del ingenuo paquero, ${ }^{3}$ de baños de mar e infantiles juegos, como otrora fuera representada en sus películas, sino más bien un lugar nocturno en el cual traspasar los límites de la ley. Hay una escena en la cual por medio de la violencia física fuerzan a otra pareja a tener sexo con ellos, los humillan y los dejan sin ropa en medio de la noche en la playa de Barra de Tijuca (al día siguiente, son hallados por la policía). A diferencia de sus películas anteriores, en ésta se encuentra un tratamiento muy explícito del sexo combinado con la violencia. Tanto el cuerpo de Virginia como el de Paulo se colocan como objetos para ser deseados. Los stripteases son tanto femeninos como masculinos. Entre ellos se plantea una situación de pares en la sexualidad, siempre están en la misma altura del plano, cada uno se saca su propia ropa, se devuelven las bromas y ella decide por su propio cuerpo -esto se remarca en el primer plano del envoltorio de la píldora anticonceptiva, que en la década del sesenta ingresó en la cotidianidad de las mujeres brasileñas-.

Con respecto a los estereotipos que señala Moreno (2001) en su trabajo, el personaje de Paulo está asociado a escenas que insinúan la prostitución homosexual. La escena más explícita es cuando Paulo toca el timbre de la casa de un hombre mayor para pedirle dinero y él le responde que su smoking lo está esperando hace una semana, lo que da cuenta de un vínculo atravesado por el dinero y regalos caros. Paulo lo llama irónicamente "Banco do Brasil". Para probarse el saco, se queda en calzoncillos. La escena alterna entre un plano general que muestra cómo Paulo se va desvistiendo y el hombre que lo mira, y primeros planos del rostro del hombre que se quita las gafas para mirarlo mejor y exageradamente se resalta que mira con deseo su cuerpo. Finalmente, lo invita al cuarto con la excusa de que vea el aire acondicionado. En otra de las escenas, Paulo espera a Virginia en la calle y se acerca un auto en el que un hombre le hace señas para subir y Paulo se niega simpáticamente. Y cuando Paulo cita al abogado para chantajearlo, lo hace en un bar de citas de hombres -así da cuenta de los espacios de sociabilidad gay carioca-.

Este estereotipo que liga la figura del homosexual con la prostitución, o relaciones atravesadas por el intercambio de dinero, en su siguiente suspense policial, A morte transparente (1978), es un poco más complejo: entre Beto, el personaje principal, y su amigo, con quien mantiene este vínculo, existe una relación de afecto. La primera

2 Uno de los evaluadores de este trabajo agudamente señaló que los nombres de Paulo y Virginia podrían constituir una referencia a la novela ilustrada de Bernardin de Saint-Pierre, Paul et Virginie (1788), que circuló en ediciones populares en el siglo XX en Buenos Aires. Aun cuando no se han encontrado fuentes que lo constaten, es probable que Christensen, que era un gran lector, realizara un juego de inversión de la pareja idílica original.

3 Flirteo en portugués. 
escena donde Beto acude en su ayuda comienza con su amigo viendo fotos de hombres sin ropa y cuando aparece una mujer desnuda se sorprende como si fuera un error; y para remarcar aún más su sexualidad, cuando Beto le pide que sea su coartada, diciendo que pasó toda la tarde allí, él le responde: “¿en la cama?" Beto lo llama coroa, remarcando la diferencia de edad que existe entre ellos y también recibe dinero de él.

Sin embargo, las siguientes escenas dan cuenta de una relación afectiva. En la escena del sauna, la cámara está muy cerca de los cuerpos sin ropa. Su amigo toma su cara muy cerca de la suya y en la siguiente escena lo masajea profesionalmente. Durante el masaje hace una referencia al cuento de Tennessee Williams "Desire and the Black Masseur" (1946), que alude al sadomasoquismo y el canibalismo: "eso es pasión", le dice a Beto, mientras lo masajea fuerte y lo acaricia, presagiando el desarrollo trágico. En otra escena en la que están ambos en calzoncillos en la cama fumando, Beto le dice que está enamorado de Marlene y que se siente podrido por eso. Su amigo le dice que sabe de qué se trata y le acaricia la pierna, mientras Beto lo llama viados. En otra escena, se le acerca un hombre a Beto en un club para hacerle compañía y lo rechaza violentamente.

Siguiendo a Richard Parker (1999), Hodgson resalta que la asociación cultural entre sexo biológico y codificación de roles sexuales que propone como activo al hombre y pasivo a la mujer tiene como resultado que un hombre pueda penetrar a otro hombre y conservar la misma identidad sexual que un hombre que solo tiene parejas femeninas -un macho-. "Su deseo homosexual queda ocluido mientras siga afirmando el comportamiento masculino en público. La sumisión a otro hombre transforma la identidad de género de un varón penetrado de macho activo a bich $a^{6}$ oviado pasivo" (Hodgson, 2012: 22). Entonces lo que podría parecer una contradicción entre el comportamiento homofóbico de Beto y la relación sexo-afectiva que se insinúa con su amigo se corresponde con los códigos del comportamiento público masculino del patriarcado. A diferencia de lo que se ha analizado en el apartado anterior, la representación de sujetos que tienen deseo sexual por el mismo sexo se vuelve más visible culturalmente en los años setenta. De 13 películas que hacen referencia a la homosexualidad en los años sesenta, el número asciende a 71 en la década siguiente. Estos cambios se vinculan con el crecimiento del movimiento a favor de los derechos de los homosexuales que terminó con la organización del primer Congreso Brasileño sobre los Derechos de los Homosexuales en 1980 (Ibíd.: 25).

A su vez, respecto de la díada bicha-macho, ambas películas colocan el juicio moral sobre los jóvenes machos del vínculo homoerótico. Ellos encarnan varios atributos de la política de la virilidad patriarcal en relación con la violencia y la dominación. Su lugar de sex toy no los victimiza, así como tampoco la mediación del dinero, sino que las bichas maduras son quienes se ven manipuladas por esta suerte de vamps masculinas. Por otro lado, es importante resaltar que todos estos personajes, así como los extras que aparecen en el sauna, en la discoteca y en el bar donde Paulo chantajea a Henrique, no están representados a partir del estereotipo del afeminado, así como tampoco estos espacios están catalogados como exclusivos de la cultura gay en el filme. El homoerotismo y el deseo por personas del mismo sexo están construidos a partir del montaje de primeros planos de las miradas y la cercanía de los cuerpos, o bien por medio de conversaciones que se interrumpen y no continúan.

A morte transparente delinea también el escenario de una juventud criminal y violenta en las zonas más ricas de Río de Janeiro. La trama abusa de las reglas del género

\footnotetext{
4 Palabra del argot. Hablar de un hombre mayor pero tampoco viejo, sinónimo de "jovato" en el lunfardo argentino. 5 Palabra del argot para referirse a los hombres homosexuales.

6 Palabra del argot para referirse a un hombre homosexual afeminado, o bien que se trasviste.
} 
convirtiéndolo al filme en algo caricaturesco. Cuatro jóvenes entran a robar a una mansión y amenazan a la mujer que vive allí con violarla. Ella, Marlene, salta a la piscina y ellos se quedan rodeándola durante horas hasta que se canse de nadar. Cuando se cansa, salen corriendo, pensando que está muerta; sin embargo, Beto, el líder del grupo, se entera de que no es así cuando es llamado por la policía. La mujer retira la denuncia y luego comienza un romance entre ellos dos. Marlene está casada con un hombre mucho mayor que ella, millonario y que vive en São Paulo. Beto, obsesionado por los celos, comienza a pensar en cómo matarlo y en un exabrupto entra a la mansión y ahoga al hombre que estaba nadando en la piscina. El crimen es cubierto por unos amigos del hombre que quieren evitar el escándalo. No obstante, tras la muerte del esposo, Beto descubre que Marlene tiene otro amante de quien está enamorada y busca huir con él. La investigación policial vuelve a recaer sobre Beto, que cuando llega a la mansión se encuentra nuevamente con el delegado de la policía, y ambos descubren el cuerpo de Marlene sin vida en la piscina porque a su vez su amante ha huido con otra mujer. Parte de la prensa describió el filme como una "revelación cruel y cínica de Río, agresivo, hostil, violento e inhumano" (s.a., 1978).

Con respecto a la figura del monstruo, esta aparece en Anjos e demônios. El abogado Henrique, acusado de homicidio, robo y acoso a Virginia, una menor, es llevado al tribunal. La prensa lo llama "abogado monstruo" y el proceso del juicio da cuenta de la condena social de este personaje. Si bien Henrique es culpable del homicidio del tío de Virginia, la película construye el patetismo de este hombre maduro manipulado por los encantos de la muchacha, eximiéndolo en parte de su culpa y dirimiéndolo a través del suicidio. Así, aun cuando enmarcado en un filme de carácter conservador en relación con el ejercicio de la violencia, nuevamente, el monstruo es aquel que denuncia la hipocresía, la indiferencia y la decadencia moral de la sociedad.

La indiferencia social frente a la violencia aparece retratada en ambas películas. En A morte transparente, hay una escena en la que Beto en pleno día en la playa frente a mucha gente le rompe la cara a otro joven con una llave inglesa y luego patea la cabeza de su novia. Se suceden algunos primeros planos de personas que pasan y miran con desaprobación la secuencia pero también con desinterés. En Anjos e demônios, en la escena en la que el grupo de jóvenes, tras una carrera de autos, molesta a una pareja de ancianos, se incorpora un plano donde vemos a un hombre que baja de otro auto para mirar la escena, y en lugar de intervenir, huye de la situación.

Hernani Heffner (2016: 6) plantea que "el fascismo sin máscara de la dictadura fue abordado, por la mayoría de los filmes, por situaciones y personajes más ligadas al cotidiano. Era menester descubrir qué había llevado a ese estado de cosas y por qué el régimen había recibido tanto apoyo inmediato". Considerando lo anteriormente expuesto sobre la intervención de Anjos e demônios en la discusión sobre la edad de imputabilidad, sería forzado y contradictorio leer la película de Christensen en relación con la violencia estatal de la dictadura; por el contrario, en una operación de sentido opuesto, da cuenta de la violencia social de la época entendida en términos antimodernos de decadencia moral, cuyo principal blanco es la juventud. Con respecto a esto, el crítico Alex Viany argumenta que es indefendible la "tesis" de Christensen que abstrae todos los factores sociales para condenar a la juventud en bloque. Agrega también que espera que sus amigos Ítalo Jacques y Orígenes Lessa -que participaron en el guion y los diálogos de la película- no sean más cómplices de otro filme tan retrogrado como éste (Viany, 1970: 4). En la misma dirección, una semana antes en el mismo periódico, José Wolf acusa al filme de ser "falso, peligroso, equivocado", que logra "fascinar a un público "estéticamente colonizado por el cine euro-americano"" (Wolf, 1970: 4). 
Al defender la tesis (policial y moralista) de que los adolescentes debían ser juzgados por el crimen cometido y no en términos de edad, el filme se equivoca con un sofisma extraño: extraño por ser distante de nuestra realidad en los años 70. Las raíces del problema de la juventud son otras [...] En las universidades, en las calles e incluso en los 'infiernitos' vive una generación que vio desaparecer cualquier estabilidad ética, que vive en un mundo por completo carente de dignidad, volcado hacia la competencia y la violencia institucionalizadas (Íd).

En ambas películas, siguiendo las reglas del género, la presencia de la ley y el Estado tiene un lugar central. En Anjos e demônios, el tío encarna la figura de la ley y el poder. En A morte transparente, está representada por la del delegado de la policía. Persigue a Beto y le dice que si no quieren crecer afuera van a tener que "hacerlos hombres" en la prisión, esta última como institución correctiva-coercitiva y delineadora de lo civilizado y de los rasgos de la política de la virilidad de la masculinidad hegemónica del sistema capitalista patriarcal. Asimismo, es quien se encarga de enunciar el mensaje moral final que lo traslada a una cuestión social, "pero lo importante es saber por qué ellos hacen estas cosas, de quién es la culpa al final". Jack Halberstam (2008: 24) señala:

En nuestra sociedad, la masculinidad se asocia a valores de poder, legitimidad y privilegio; a menudo se la vincula, simbólicamente, al poder del Estado y a una desigual distribución de la riqueza. La masculinidad parece difundirse hacia fuera en el patriarcado y hacia dentro en la familia; la masculinidad representa el poder de heredar, el control del intercambio de las mujeres y la esperanza del privilegio social.

De esta manera, el tío, los jueces y el delegado de la policía encarnan la figura del Estado patriarcal que resulta triunfante en ambos filmes.

Según el crítico Ely Azeredo, quien en otras ocasiones ha sido muy duro con Christensen, Anjos e demônios tuvo una excelente recepción por parte del público. En su crítica resalta la competencia de este "filme-espectáculo" volcado a un amplio público y aprovecha la oportunidad para criticar a los cineastas de la Boca do Lixo (Azeredo, 1970: 2). Las carteleras de ese mismo periódico también registran su exhibición en el circuito comercial por un período de 10 semanas. Retomando la propuesta sobre la circulación de los géneros, ambos filmes dialogaron con el aumento de los filmes eróticos en la producción nacional, sobre todo con la consolidación como género de la pornochanchada en la década del setenta. En ambas películas, como se ha señalado, el sexo y el erotismo heterosexuales son sumamente explícitos y es probable que el homoerotismo haya pasado más desapercibido. No obstante, si bien los dos filmes plantean una mirada conservadora, y en algunos aspectos reaccionaria, de la conflictividad social, en el plano de la sexualidad proponen subjetividades que desafían a la heteronormatividad y se tornan artefactos de la cultura de masas con una potencialidad política.

\section{A modo de cierre}

La filmografía de Carlos Hugo Christensen en Brasil presentó una gran heterogeneidad en materia de géneros, ensayando diferentes estrategias de producción que propusieron diversas formas de hacer cine en Brasil. No obstante, su obra durante varias décadas no recibió la atención de la crítica y la historiografía. La mayoría de sus películas fueron percibidas como pasatistas y alienantes en un escenario de ebullición política.

Es por ello que este trabajo propuso pensar la potencialidad política de estos objetos de la cultura de masas a partir de una relectura sobre su carácter disruptivo del orden 
en función de las imágenes del homoerotismo, los desafíos a la heteronormatividad y a la política de la virilidad hegemónica que las diversas masculinidades representadas en sus películas configuraron.

De esta manera, siguiendo el planteo de la tesis de Hodgson, se ha buscado analizar los elementos de inversión y desestabilización de la lógica binaria y de las identidades y categorías fijas sobre la cual se funda el orden burgués. Así, se ha estudiado, por un lado, la limitación del lenguaje en la ruptura o fisuras del orden binario. Por el otro, la fluidez de roles y sus inversiones al analizar los vínculos homosexuales y el homoerotismo, considerando variables como la edad y la clase, como elementos no de ruptura pero sí de desestabilización.

Se han elegido filmes del género policial, o con elementos de éste, porque abren la posibilidad de pensar estas masculinidades y la política de la virilidad patriarcal en relación a la violencia y el poder del sistema en su conjunto. Estos "anormales" o "monstruos" son portadores de discursos que potencialmente diluyen las relaciones de dominación de la masculinidad hegemónica por su propia inestabilidad, porque no tienen lenguaje y requieren otro nuevo. Como se ha dicho, el monstruo es el que pone en jaque al orden y por eso es condenado y se lo diferencia de la identidad homosexual fija, funcional al sistema patriarcal.

Aun cuando estas películas frente a la conflictividad social se posicionaron en lugares muy conservadores, desde una mirada de género, pusieron en escena subjetividades que desafiaron las relaciones de poder de las masculinidades en el contexto histórico del Brasil entre las décadas de 1960 y 1970. En diálogo con el crecimiento del erotismo como tema y forma, entre el sexo heterosexual explícito, estos filmes introdujeron fisuras y transgresiones que desestabilizaban al orden social y moral de la época. 


\section{Q Bibliografía}

»A notícia, Rio de Janeiro, 3/8/78.

"Alencar, M. (1966). “Christensen, O menino e o vento". Jornal do Brasil, 9 de noviembre de 1966, 5 .

»Altman, R. (2000). Los géneros cinematográficos. Barcelona: Paidós.

"Azeredo, E. (1970). “Sin título”. Jornal do Brasil, 4 de marzo, 2.

»Bernini, E. (2021). “El noir peronista. Christensen y la trilogía William Irish”. En: Setton. R. y Pignatiello, G. (eds.), El género policial argentino en el período clásico (1930-1960) entre Sur y el peronismo. Modelos narrativos, tensiones y debates culturales. Harlingen (Texas): Libros Medio Siglo, 2021, 213-219.

»Butler, J. (2007). El género en disputa. El feminismo y la subversión de la identidad. Barcelona: Paidós Ibérica.

»Cánepa, Laura Loguercio (2008). Medo de quê? Uma história do horror nos filmes brasileiros. Tesis de Doctorado, Universidad de Campinas, São Paulo, [s.n.].

"Cavalcanti de Paiva, S. (1967). "Sin título". Correio da Manhã, 10 de septiembre, 2.

"Connel, R. W. (1997). "La organización social de la masculinidad”. Valdes, T. y Olavarría, J. (eds.), Masculinidad/es: poder y crisis. ISIS-FLACSO: Ediciones de las Mujeres $\mathrm{n}^{\circ}$ 24, 31-48.

»Correio da Manhã, 13/9/66, 1.

»Correio da Manhã, 18/9/66, 10.

»Correio da Manhã, 20/8/67, 6.

»Christensen, C. H. (1966). O menino e o vento. Brasil.

»Christensen, C. H. (1969). Anjos e demônios. Brasil.

»Christensen, C. H. (1978). A morte transparente. Brasil.

» Freire, R. de Luna (2011a). Carnaval, mistério e gangsters. O filme policial no Brasil (1915-1951). Tesis doctoral, Universidade Federal Fluminense. Programa de Pósgraduação em Comunicação.

»Freire, R. de Luna (2011b). "Descascando o abacaxi carnavalesco da chanchada: a invenção de um gênero cinematográfico nacional". Revista Contracampo, no $23,66-85$.

» Giorgi, G. (2009). “Política del monstruo”. Revista lberoamericana, Vol. LXXV, no 227, abril-junio 2009, 323-329.

»Halberstam, J. (2008). Masculinidad femenina. Madrid: Egals.

»Heffner, H. y Sauerbronn, R. (2016). A vilania no cinema brasileiro. Rio de Janeiro: SaraguinaFilmes y Jurubeba Produções.

» Hodgson, J. N. (2012). Male Homosexuality in Brazilian Cinema of the 1960's and 1970's. Tesis Doctoral, University of Manchester. Faculty of Humanities, School of Arts, Languages and Cultures.

"Hora Góis, J. B. (2002). “Homossexualidades projetadas”. Revista Estudos Feministas, 10, no 2, 515-518. 
Lopes, D. (2004). "Desafios dos Estudos Gays, Lésbicos e Transgêneros”. Comunicação. Mídia e Consumo, vol. 1, no 1. En: http://revistacmc.espm.br/index.php/revistacmc/article/view/5/5; obtenido el 05.08.2020.

» Mittell, J. (2004). Genre and Television: from Cop Shows to Cartoons in American Culture. New York: Routledge.

"Moreno, A. (2001). A Personagem Homossexual no Cinema Brasileiro. Rio de Janeiro: Funarte/ Eduff.

»O Jornal do Brasil, 23/2/70, 4.

"Primati, C. (2015a). “O menino e o vento”. En: Puppo. E. (org.), Retrospectiva Carlos Hugo Christensen. Rio de Janeiro: Caixa Cultural.

"Primati, C. (2015b). “Anjos e demonios”. En: Puppo. E. (org.), Retrospectiva Carlos Hugo Christensen. Rio de Janeiro: Caixa Cultural.

» Ramos, José Mário Ortiz (1993). “A questão do gênero no cinema brasileiro”. Revista USP, 19, 109-113.

»Viany, A. (1970). O Jornal do Brasil, 13/3/70, 4.

"Wolf, J. (1970). “O filme em questão. “Anjos e demônios’”. O Jornal do Brasil, 6 de marzo, 4. 
